\title{
Food Crises Management in the Pharaonic and the Ptolemaic Periods
}

\author{
Tarneem Farag Bayoumy ${ }^{1}$ Wessam Fekry Ibrahim ${ }^{2}$ \\ ${ }^{1}$ Associate Professor, Faculty of Tourism and Hotels, Matrouh University. \\ ${ }^{2}$ Assistant Professor, Faculty of Tourism and Hotels, Matrouh University.
}

\section{ARTICLE INFO}

Keywords:

Food Crises

Crises Management

Pharaonic

Ptolemaic

(JTHH)

Vol. 3 No. 1, (2021)

pp 1-20.

\begin{abstract}
In ancient Egypt, food crises occurred due to several reasons as bad harvests, climate change, wars, economic and diplomatic reasons. The inundation level of the Nile River was irregular, sometimes low and other times high that is why food crises happened frequently. Food crises were ranging from food shortages to great famines. Some archeologists relate the collapse of the Old Kingdom to food crisis as a result of climate change. The idea of food crises management reflects the efforts of ancient Egyptians and the Ptolemies in protecting land from the Nile's flood and sustaining agricultural activities by building dams, canals, storing and distributing food. Food crisis was recorded clearly in the autobiographical inscriptions of the rulers of the 1st Intermediate Period. In the Ptolemaic Period many food crises were recorded as well, the most famous of which was during the reign of Ptolemy III which was recorded on the Canopus Decree and that of Ptolemy V on the Rosetta Stone. This paper aims at displaying a historical background of food crises from early Pharaonic period till late Ptolemaic period, shedding light on management tools to overcome the crisis. The study also conducts an analytical study of the Pharaonic and Ptolemaic periods in regards to food crisis reasons and management. The research revealed some similarities as well as some differences between the two periods.
\end{abstract}

\section{Introduction}

Water is one of the most important requirements for all forms of food production. "Water is mankind's most valuable resource", "No Water, No Food" (Andelman, 2010; El Bedawy, 2014). Water shortages occasionally happened in ancient Egypt due to geographical features, climate change, and political conflicts, which led to storage of water as a management tool. This made ancient Egyptians adapt to water shortages. Adaptation can sometimes prevent or avoid harm, grease benefits and opportunities (Lewis and Maslin, 2015). By the late Predynastic times, People started building canals and other waterways (Larry, 2010). After large famines in Egypt, villages were left depopulated (Yofee, 2019). Reference to food crisis in ancient and Ptolemaic Egypt occurs in several texts, some have been widely studied by Vandier, who explained that evidence is scanty because the Egyptians did not desire to record inconvenient actions (Vandier, 1936). Vandier did not find a lot of documents concerning famines in the Old Kingdom, and he related that to the strong central government making it easy to store up large excess water during high flood and dispute them in low floods. (Bell, 1971). It appears that some words (like $\mathrm{krj}$ ) in the ancient Egyptian language covers the idea of a 'marginal poverty' 
that relates to a small segment of the population who probably lived on the borderline of the society (Driaux, 2020). "Famine" could be identified as "critical shortage of essential foodstuffs, leading through hunger to a substantially increased mortality rate in a community or region, and involving a collapse of the social, political and moral order" (Garnsey 1998) In classical sources the word 'Famine' is normally used to refer to any food crisis (Garnsey, 1988). Famine and disease are usually linked together. In ancient Greek, the words are closely and easily confused," limos" is starvation, "loimos" relates to epidemic disease (Bourriau, \&Porter, 1992). Documentation for a historical overview of food crisis during Ptolemaic Period did not mention or refer to any dramatic increase in a population's mortality rate, the famines defined here during the Ptolemaic Period is more likely to be less serious than famines, more of food crisis or food shortages. It is worth mentioning that what is meant by "Food Crisis" in this research in the two periods mentioned ranges from food shortage to great famines. Studying food crisis during these periods is valuable in enabling us with a realistic problem scale assessment and confirms that the authorities' quick responses and their interventions caused the crisis to be overcome.

\section{Crisis management}

Seeger \& Ulmer (1998) defined the crisis as "an unexpected, specific, and nonroutine event/series of events." They also determined the main three components of crisis; (a) Threat, which is a trigger event that could cause some dramatic occurrences, (b) Short Response Time, which is critical in reducing the harms and (c) Surprise, being suddenly confronted with unlikely circumstances. Venette thinks that crisis is a transformational process in which the previous system could not be maintained anymore. Dealing with threats before, during, and after they occur is part of crisis management (Venette, 2003). According to Bundy Crisis management is the process of dealing with disrupting and unpredictable incident that threatens to affect the system (Bundy, et al, 2017).

In light of the previously mentioned studies and definitions of crisis management, it will be interesting to investigate the methods of managing food crises in the Pharaonic and Ptolemaic periods and compare between two broader frameworks of management that consists of different skills and strategies in dealing with food crisis.

\section{Objectives of the Study}

- Investigating the reasons of food crisis in Ancient Egypt (in Pharaonic and Ptolemaic Periods).

- Displaying examples of food crisis in the Pharaonic and Ptolemaic periods

- Shedding light on food crisis management in the Pharaonic and Ptolemaic periods

- Analyzing and comparing between food crisis in the previous two periods in regards to reasons, how it was recorded and the management of food crisis in the two periods.

The following part will display examples of food crisis in a chronological order from Pharaonic to Ptolemaic periods and the management actions in each period. Not every document was included in this study but a large number was discussed to have a sufficient idea of each period and its management.

\section{Examples of Food Crises in the Old Kingdom}

Scientists in 2012 stated the discovery of ancient pollen and charcoal found in deep grounds in the Nile Delta that indicated ancient fires and droughts. The records included many big droughts: one that took place around 5,000 to 5,500 years ago, one around 4,200 years, when the Old Kingdom collapsed and one that took place around 3,000 years ago (ScienceDaily: Your Source for the Latest Research News, 2012). It is now accepted that this drought might have lasted between 20 to 25 years, from the end of Dynasty VI to the beginning of Dynasty 
IX, around 2180 to 2160 BC (Hayes, 1961; Wilson, 1956; Gardiner, 1961). Evidence of the trouble which took place at the end of Dynasty VI indicate that warfare between districts took place, looting, revolution and absence of government (Bell, 1971).

In the late Old Kingdom, large population movements similar to those caused by a drought is shown in the reoccupation of the Nile Valley, and Sinai (Yofee, 2019). Hassan (2007) suggests that this drought, and its consequent famine, led directly to the fall of the Old Kingdom. Hassan's study was based on the decorations of Old Kingdom tombs. The data suggested that the number of instances of marshland related scenes appeared to decrease from Dynasty Five onwards. The first famine clearly appears during the $3^{\text {rd }}$ dynasty, reign of king Zoser but recorded in the Ptolemaic Period as will be discussed later (see infra p.9). A relief from the causeway of the Pyramid of Unas(end of Dynasty V) shows a group of starving people (Drioton 1942, Smith 1965). There is no explanation of this scene, their nationality or the cause of their starvation whether due to low Nile flood or the ending of the Neolithic Wet Period rains (Bell, 1971). Inscriptions in tomb of Meri I at Athribis (end of Old Kingdom) mentions that during the season of "prt "(winter)" snb ib" (the years of famine)," $s$ ' $n h s w 3$ "I have lived the poverty. "snb ib", also appears in an inscription in the tomb of Sennedjsou from Danderah (end of the Old Kingdom)" (Vandier,1936; Urk,I, p.266,I,10).

\section{Food Crisis Management in the Old Kingdom}

The first known large-scale dam for water management was Sadd-el-Kafara Dam, known by "the Dam of the Pagans", located in Wadi Garawi, $30 \mathrm{kms}$ south of Cairo and around $11 \mathrm{kms}$ southeast of Helwan on the eastern Nile bank. The dam was probably built to control the flood in 2650 B.C during the Old Kingdom (Fahlbusch, 2009; Larry 2010). The dam intended to store 0.5 million $\mathrm{m} 3$ and with height of 14 meters and length of 113 meters (Schnitter, 1994). The purpose of the dam was to store the largest flood in Wadi el-Garawi, the reservoir area of the dam contains little silt so it is assumed that it was not used for a long time. It is obvious that water management during that period associated flood control with water storage for irrigation (Sharma,.\&Saxena 2004). Measuring and recording of the annual flood was also important through the "Nilometer", which is a device in the form of a descending staircase leading down into the river, where markings of the rising water was recorded. Accordingly, the level of taxes was estimated. Less than 6 feet below the target would mean food shortages or a famine and 6 feet over the ideal would also mean an overflow Nile destructing dams, dykes, and probably flooding entire villages (Rutz, 2001).

\section{Examples of Food Crisis in the $1^{\text {st }}$ Intermediate Period}

Autobiographical inscriptions of rulers of the $\mathbf{1}^{\text {st }}$ Intermediate Period and Middle Kingdom present high officials as the ones who saved their people during crisis. Khety II, ruler of Assiut during the First Intermediate Period (dynasty X). In his tomb inscriptions is mentioned " $r n p t$ $n d s$ ", year of low flood and "rnpt Ksnt", year of misery (Breasted,1906). In Hat-Nub Graffito 16 (dynasty $\mathrm{X}$ ), it is clear the role of rulers in drought time in protecting their people against the intruders from the Nubians and Asiatic and how they leagued the north and south of the country (Vandier,1963). In Hat-Nub Graffito 20, is mentioned year of low flood " rnpt tsw", and In Hat-Nub Graffito 23,24, the role is shown in the protection of his village in the day of violence and terrible fear, I opened " $̌ n w . i n ~ b w n b w$ " my granary to all the world ( for complete text see Vandier,1936,pp.103-104). Ankhtify, who was nomarch of Hierakonpolis and Edfu, his inscriptions in his tomb at Mo'alla ,in the south of Luxor, studied by Vandier (1950) mentions that except in his nome, Upper Egypt was dying of hunger $(h k r)$, which led people to eating their own children, but he managed that no one died of hunger in his nome. (Vandier,1950, Bell,1971). Vandier discusses 9 funerary stelae which records that the ruler saved his town by distribution of grain during famine. Hayes (1961) discusses some of these 
stelae. The first seven come from the time of Inyotef I, I) Stele of Djari, of Qurneh (dates back to the $1^{\text {st }}$ Intermediate Period, and is now present in Musee Royal at Bruselles, E.4985): explains how he was a great provider for their houses, in the year of famine " $r n p t s n b-i b$ ", he gave to those whom he did not know as well as to those whom he knew (Vandier,1936).

\section{Examples of Food Crisis in the Middle Kingdom}

A Hymn to the Nile (Wilson 1955), most probably, in the Middle Kingdom. associated with a low Nile explains how people were few, people carried weapons and no garments for clothing and ornaments for children. The Hymn might reflect memories of several years of low Niles during the First Intermediate Period (Bell,1971). Biblical accounts of a famine as a result of drought in Egypt during the $2^{\text {nd }}$ millennium BC (Middle Kingdom) describes how Joseph predicted and managed its consequences (Alien, \& Prentise, 2013).

\section{$11 t^{h}$ Dynasty}

The stele of Iti of Gebelein ( $11^{\text {th }}$ dynasty, now in the Egyptian museum in Cairo, CG 20001) explains how the owner made Gebelein live during the years of misery (rnpt Ksnt), fed his brothers and sisters, buried the dead and fed the alive, shut their fields and did not allow their water to inundate for someone else, transported barley to the town.3) Stele of Hekaib (BM 1671), from Gebelein, and according to Vandier (1936, 1950), contemporary with Iti. It records how he provided the town with grain from upper Egypt for many years, gave oil to Hierakonpolis. 4) Stele of Djhouty of Qurneh (11 ${ }^{\text {th }}$ Dynasty). It records how he supplied the temple of Amun during the years of misery (ksnt)" (stela is published in Petrie,1909). 5) Turin 1310, shows how the owner repelled the years of low Niles (tsw) from the land. 6) Stele of Antefoker (BM 1628), shows how he gave barley and wheat to the hungry, and supported everyone during the famine ( $h k r w$ ), so that no one died. 7) Stele of Senni (Cairo 20500): how he measured out grain of Upper Egypt for the town during the miserable years of famine $(k s n t$ $n t s n b-i b) .8)$ The stele of Ideni of Abydos (11 th dynasty, CG 20502), records how he gathered his energy in the day of misery (hrw $n$ ksnt)". 9)The stele Cairo 20503: records how he nourished his town, in the year of misery $(k s n t)$. The reign of Mentuhotep III was considered prosperous, but there is one document, a letter directed to his family by Hekanakht when he was on a trip during a famine caused by a low Nile. (Bell,1971, Sally 2012).

\section{$12^{\text {th }}$ Dynasty}

In inscriptions from the tomb of Ameni at Beni Hassan, who was a ruler under Senusret I, he claims that he preserved his Nome in "rnpw hkrw" "years of hunger" through a policy of land management (Newberry, 1893).

\section{The $2^{\text {nd }}$ Intermediate Period}

\section{$13^{\text {th }}$ Dynasty}

From the tomb of Sebek--Nakht at El-Kab, it is mentioned how he was a man who protected " $n h m$ " the afflicted against the mighty, "mh šnw nt ntr $m$ ", filled the granaries of the god with corn (Tylor, The Tomh of Sebeknakht, pl. VII. I. 1 2).From the tomb of Bebi at El-Kab, " rdi.n $n$ niwt $m$ hkr nb", I have given corn to the city during each famine (Vandier, 1936, p.115).Stelae Cairo CG 20537 of Horherkhoutef, found at Edfu, is the usual "I gave bread to the hungry, clothes to the naked...", " csd.n (i) niwt.i $m$ h $k r$ ", I have saved my town from hunger( LangeSchafer in "le Catalogue général du Musée du Caire $n^{\circ}$ 20537). From tale of coming back of Khonsuemheb " $m$ prt $h k r$ ”, in winter of famine(hunger).

\section{Food Crisis Management in the $1^{\text {st }}$ Intermediate Period and the Middle Kingdom}


High officials claimed that they were able to manage food crisis in the First Intermediate Period through digging canals, providing irrigation to drought- lands through planned water management and the efficient distribution of food. The stelae of Iti and of Merer contain Thebes looking for grain, and it shows Merer's efforts to increase his family's supply (Bell,1971). In the Middle Kingdom, the depression of Fayoum was connected to the Nile by an artificial canal (Bahr Yousef) (Shabrawy and Dumont, 2009) and formed a lake which worked as a neutral zone for floods (Larry, 2010). The construction of canals expanded irrigation areas in Faiyum and flood control brought water and nutrition to the depression (John, 2011).

\section{Examples of Food Crisis in the New Kingdom}

In the Magical Papyrus Leyden I (Ipuwer), " $n n h k r n n i b n n \underline{h r} i^{\complement} d t r n p t ”$, I will not be hungry, I will not be thirsty, I will not fall during the famine (Leyde, Papyrus Magique, I, p.347). Hayes, think that Ipuwer, the ruler of Edfu, was most probably an eye witness of the anarchy including tomb robbery, and infiltration of the Delta by Asiatics. Ipuwer Perhaps the year that he became ruler of Edfu, found some areas flooded due to the inefficiency of his predecessor, he stated that the inhabitants of the Delta carried shields, and the plunderers were everywhere (Bell,1971). Parkinson (1997) thinks that Ipuwer's text presents a dialogue, between him and the creator and was not directed to a particular king, but to the representative of authority. Ipuwer also expressed his doubts and uncertainty, by wondering how could God allow such a state of affair to happen and why he did not prevent it. In Papyrus Anastasi IV (reign of Seti II), "come Amun protect me from this year of famine" (Vandier,1936). In London medical papyrus BM EA 10059, line 17,2, the mention of the word $h k r$, also in London BM 9900 (Nebseni,) line 5, 20, Harris 500 BM EA 10060, Recto 1-4, Berlin 14424 a,14433 a, Chester Beatty V BM EA 10685, Recto 1-5. And Ashmolean Museum 1945,40, Deir el Medina, Sinuhi line 58

In the late Nineteenth and Twentieth Dynasty documents provide references to hunger and the purchasing power of foodstuffs, showing possible administrative inefficiency. In the $20^{\text {th }}$ Dynasty, the workmen of Deir el- Medina went on a strike to obtain their salaries. Egypt was famous then for its prosperity and wealth in the near east. New Kingdom kings presented grain supplies as diplomatic gifts for their allies, especially the Hittites, who were facing starvation (O’Connor 1982, Kemp 2006, Contardi 2015).In Papyrus Harris 75 (reign of Ramesses III), mentions " $m$ rnpt šwit" in years of misery(Papyrus Harris 75, 2/7). In Papyrus of British Museum $\mathrm{N}^{\circ} 10052$, mention "years of the hyaenas, being hungry" (Peet, 1930). There were repeated complaints of food shortages after the reign of Ramesses III till end of the Ramesside period documented by Deir el Madina community reflecting more bad economic conditions( Kemp, 1991).

\section{Food Crisis Management in the New Kingdom}

In the $20^{\text {th }}$ dynasty, documents claim that during the reign of Ramesses III, the cause of the food crisis was the administration itself through the diplomatic gifts from the granary storage, which led also to the failure of the payment of the workers in Deir el Madina. The cause and management of' food crisis was from the administration.

\section{Examples of Food Crisis in the Late Period}

On a statue in the Egyptian Museum in Cairo, dating to the $\mathbf{2 2}^{\text {nd }}$ dynasty (Borchardt, 1934,no.559), "having lived the poverty of my town" $s$ 'nh $n$ niwt.i". Two fragmentary stelae in the Egyptian museum JE 48440 (from Coptos), 38265 (from Mataanah), dating to the $\mathbf{2 5}^{\text {th }}$ dynasty, reign of Taharqa represent the role of the king "his majesty" in maintaining the Nile level through his prayers to the god Amun-Ra, the words used are " $d b h h^{c} p n$ 'Imn $R^{e}$ ", asked a Nile (abundant) from his father Amun Ra (Vikentiev,1930). 


\section{Food Crisis Management in the Late Period}

It seems that the management of food crisis in this period is not clearly recorded, except for the role expected from the Gods in overcoming the failure of the floods and the management of the water.

\section{Examples of Food Crises in the Ptolemaic Period}

Egypt's wealth increased greatly during the Ptolemaic period. The Ptolemies, understanding the advantage they could derive from the privileged country which they governed, encouraged the cultivation of grain, and greatly improved the methods of cultivation (Mokyr, 2003): excellent fertilizers were used, crop rotation and irrigation works developed more and more. Although silver currency had been introduced in Egypt, land tax on grain was still used (Vandorpe, 2005). Finally, trade had flourished under the influence of the Greeks (Muhs, 2016). However, the dynasty experienced some periods of instability and unrest. These included Egyptians revolutions against the Greek Ptolemaic rulers and socioeconomic stress (Lloyd, 2014). The increased inherited land sales or abandonment, indicating that families couldn't grow sufficient crop yield to pay taxes, in additions to the frequently issuance of priestly series official decrees, or royal ordinance prostagma, to maintain the royal control are all signs of the instable circumstances (O'Neil, 2012). Obviously, the situation was worsened by severe droughts and crop shortages during seasons when the Nile River did not flood according to its annual cycle.

\section{Literary and Royal Evidences:}

The reference to an early food scarcity dated to the time of Cleomenes of Naucratis, he was a financial administrator, placed by Alexander the Great as governor of Egypt in 332/1 BCE, with an overall authority for the country's finance system (Bosworth, 2016). According to the Aristotelian Oeconomica (Goettling, 1830), he was a master of profiteering and investment as during a period of a proper international famine and grain scarcity in Egypt, likely in 330/329 B.C, he forbade grain's export and gathered Egypt's whole grain surplus in his hands to resold it for a massive profit (Whittaker, 2020). He dedicated a considerable expense to the huge public buildings of Alexandria (Bosworth, 2016). Although the Oeconomica did not explain the reasons of the famine and the lack of crops in that period, it provides us with important evidence of the policy followed to deal with the crisis (preventing exports and monopolizing the market) and even benefiting from it (raising the price of exports) to achieve profits (exchange on government projects)

A basic conclusion can be drawn from this evidence that grain export from what was to become Ptolemaic Africa to other Mediterranean areas suffering from food shortages or famine began in the early Hellenistic period. Besides, Cleomenes' strategy in managing this situation and controlling the export of grain was certainly important for the Ptolemies to consider as they drew up their strategic framework for the administration of their empire.

Literary evidence for a severe grain scarcity in Egypt under an unspecified Ptolemy is included

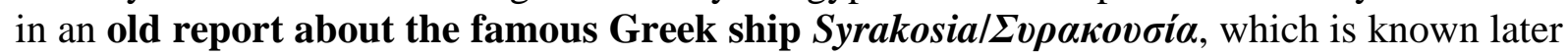
as Alexandris/A $\lambda \varepsilon \xi \xi_{\alpha} v \delta \rho \varepsilon 1 \alpha$, built by Hieron II at Syracuse and sent as a gift fully loaded with 90,000 bushels ( $\mu \varepsilon \dot{\delta} 1 \mu v o /$ médimnoi) of grain, 10,000 jars of salt-fish in addition to other thousands of goods to Ptolemy as there was a food crisis throughout Egypt (Athenaeus, Book V. 40). Casson identified the Ptolemy in question as Ptolemy Euergetes I (Casson, 1971) then both of Hauben (Hauben, 1981) and Lehmler (Lehmler, 2005) accepted the same identification. On the other hand, the incident was chosen by Rostovtzeff to be dated under Ptolemy Philadelphus (Rostovtzeff, 1953).

A second significant proof to the identical issue and its parameters is ensured in the famous Canopus Decree (Cairo, CG 22187). Euergetes's immediate 
intervention to save Egypt from a threatening consequences of low Nile flood is highlighted in that decree as one of his benefactions towards his subjects.

Around 245 BC Ptolemy III took a move that still puzzles many scholars and historians, as after a successful military campaign against the Seleucid Empire, Ptolemy III, unexpectedly returned home. (Grainger, 2010), however, according to the preserved chronicles of Roman historian Justin, he would have proclaimed himself ruler of all Seleucus' kingdom if he hadn't been compelled to return home in 245 BC (Justinus, 2011). Droysen thought that his return was due to a revolt in the Cyrenaica (Droysen, 1877), a hypothesis rejected by Mahaffy who thought that there was unrest in Egypt as a result of a defective rise of the Nile and the possibility of famine (Mahaffy, 2014). The Canopic Decree of March 7, 238 BC (Cairo, CG 22187) indicates that during the reign of Ptolemy III the Nile had not risen. There was a great stir among the Egyptians, who remembered the catastrophes which had occurred before, during the days of previous kings in consequence of the Nile's deficiency. To overcome this situation the Canopus Decree referred that the king did the following actions; spend a lot of white gold to import grain into Egypt from Syria, Phoenicia, Cyprus and from other lands, remit many taxes and transport the importation of supplies to save the Egyptians (Budge, 2014), (Cairo, CG 22187). The king, according to the previous document, had imported at his expense a large quantity of grain to avoid famine, and had remitted many taxes to allow the economic recovery of the country. This action may take us back nearly two thousand years to the time of the Middle Kingdom which faced the same threats (Vandier, 1936). However, among the means employed by Ptolemy Euergetes to avoid famine, was the importation of grain which was a new guarantee that the Middle Kingdom had not known.

The decree also reflects the existence of a precise and painful vivid memory in everyone's mind of a terrible disaster happened under previous kings following a low Nile. It would be very interesting to be able to specify who were these former kings. Vandier, depending on the Egyptian expression tpjw-a, suggested that they are distant ancestors. At the same time, he emphasized that it is not allowed to deny absolutely the existence of famines under the first two Ptolemies, and the kind of terror reflected in this passage from the decree of Canopus would agree better with recent and lived suffering than with an ancient one (Vandier, 1936). Buraselis also preferred to dated such challenges to Egypt's recent past since Alexander (Buraselis, 2013). Whoever were those kings it is obviously from the decree that they were not able to face the disaster as efficiently as Ptolemy III. Moreover Buraselis, considered Euergetes, " $a$ Mediterranean crisis manager" more than being just a king concerned with the wellbeing of his subjects (Buraselis, 2013).

Although the main cause of the crisis, according to the Canopic Decree, is the bad Nile River, there is another reason, regardless of not being explicitly mentioned, that can be deduced. Fiscal demands and pressures on rural production to support the Third Syrian War may have deepened the crisis (Monson, 2012).

The most well-known document of famines during the Ptolemaic Period, is The Famine Stela. It is an inscription carved in Egyptian hieroglyphs on Sehel Island in the Nile near Aswan, explains a seven-year drought and famine that occurred during the reign of the Third Dynasty king Djoser (Arregui et al., 2020). Although the text claims to represent a royal decree of the early Old Kingdom, the stele is assumed to have been carved during the reign of Ptolemy V. Some researchers (e.g. Barguet, 1953) simply project the year 18 (of Djoser) mentioned in the text onto Ptolemy V and therefore date the writing to $187 \mathrm{BC}$.

The stele appears to document Djoser understanding the cause of a lengthy sequence of Nile flood failures in a dream, as well as the solution. What is important for the scope of the study 
in this part is the indication to the crisis solution which was namely by supporting and restoring the cult of the God Khnum at Elephantine Island, who was responsible for the Nile sources (Pinch, 2004). While this passage is almost certainly a fake from Ptolemy V's reign, it does indicate an ontological interest in the establishment of Khnum's temple lands at Elephantine (Connor, 2015).

The Memphis decree/Rosetta Decree under Ptolemy V Epiphanes confirms that. The decree was issued at Memphis by Egyptian priests in 196 BC to commemorate Ptolemy V's victory in the Nile Delta over native Egyptians who were actively revolting against the Ptolemaic rule. There is mention of an amnesty (OGIS I, 90 1.27-8) which, with the exemption from taxes, proves to us that Egypt was, at that time, largely ruined by the civil war and by the famine which is the logical consequence. It is worth focusing here on that "amnesty". The Rosetta Stone has gotten a lot of attention as a significant historical record. The fact that the inscription commemorates a debt cancellation declaration issued by King Ptolemy V in Memphis in 196 B.C was part of his strategy of economic revival is less well known (Hossein-Zadeh, 2014). The debt cancellation highlights a declining economy plagued by taxes pressure, confiscations, prisons overcrowded with lawbreakers and public and private debtors (Hudson, 1993).

Hossein-Zadeh, interestingly, stated that Epiphanes's economic revival strategy, through amnesty, in the face of widespread economic decline and indebtedness which contrasts sharply to today's economic policy makers practices in advanced market economies, was more sufficient than modern strategies that have deepened the relentless recession (Hossein-Zadeh, 2014).

Two additional important late Ptolemaic examples show how much more difficult the circumstances in Egypt really might have become in a time when similar royal methods and such a broader network of mobilization during a grain crisis mainly failed to function. In the earlier example, difficulties and challenges that could have been solved in a better period of Ptolemaic Kingdom through royal outlay and coordinated imports would have to be managed now by sacrificing the truly critical interests of the majority of the country to the advantage of those within the capital (Buraselis, 2013). A papyrus dated 27 October 50 B.C (C. Ord. Ptol. 73) refers to the situation during the Cleopatra VII's early co-rule with her brother Ptolemy XIII. It is a royal ordinance prostagma regulating the sale of grain and legumes from Middle Egypt to Alexandria and forbidding sales to Lower or Upper Egypt. A violation is punishable by death. The incentive to denounce is: $1 / 3$ of the property for a free person, 1/6 of it and freedom for a slave (Verordnung über die Versorgung Alexandreias: Ägyptisches Museum und Papyrussammlung: Museum-digital:staatliche museen $\mathrm{zu}$ berlin, 2021). Though the decree looked sharp and oppressive, threatening lawbreakers with expropriation and even death, while encouraging spies and informants. It seems likely that, in this way, the rulers wished to prevent the food shortage riots which were almost there in Alexandria (Hölbl, 2013). Cleopatra attempted to manage the problem: she couldn't do anything about the Nile's low level, but she did try to control greedy royal officials who were pestering peasants, and she distributed grain from the royal storages (Roller, 2010).

Cleopatra was intimately involved in the administrative operations of her territory, confronting crises such as famine through directing royal granaries to provide food to the starving public (Roller, 2010). Although some have accused her of neglecting Alexandria's Jewish population in her famine relief program (C. Apionem, II 60), this is an indication that she followed a policy of distributing grain among the residents during the crisis period. Anyway, Roller did not believe this opinion, confirming that her broad religious policy allowed her to restore the inviolability of a synagogue, most likely in Leontopolis (Roller, 2010). The second case is a text from Thebes (OGIS 194). The text, inscribed in demotic and Greek on a reused granite 
stela dated back to the New Kingdom (Badian, \& Sherk, 1985) honors the local governor Callimachus who devoted himself to protect the local residents and supplied each one of them with all kinds of food during a famine that lasted at least a year. The inscription most likely dates from 39 B.C (year 13 of Cleopatra's reign), although it was written in response to the ongoing famine and social unrest in the late 40s B.C (Cole, 2018).

\section{Evidences for Food Crises/Shortages in Classical Sources:}

Evidences for famine during late first century B.C and the linkage between the agriculturally crucial Nile River inundations and political unrest are well recorded in classical sources, particularly the severe Nile floods in the late 40s B.C (Forsyth, 1988). The Nile did not flood for two consecutive years, according to Seneca ( $N Q 4 \mathrm{~A} .2 .16)$, in the tenth and eleventh years of Cleopatra's reign. Appian probably verified this (Appian, Civile 4.61), saying that Cleopatra refused to help Cassius in 43 B.C because Egypt was ravaged by famine and diseases. Again, Appian stated that Egypt was once more devastated by famine, and that Octavian and Antony couldn't get grain supplies from Egypt around the time of the Battle of Philippi in October 42 B.C. because "the country was exhausted by famine" (Appian 4.108). Despite the fact that Seneca and Appian were writing one and two centuries after the incidents, the contemporary honor decree for Callimachus in 39 B.C supports their story (Cole, 2018).

A recent study conducted by Joseph R. Mcconnell, Desert Research Institute, Reno, NV, in association with a team revealed that the climate change following the massive eruption of Alaska's Okmok volcano in 43 B.C affected and played a vital role in the collapse of the late Roman Republic and Ptolemaic Kingdom. It most likely exacerbated the Nile flood's normal interannual instability. For the same years, historical sources show concomitant food shortages and disease outbreaks.

\section{Temples' Inscriptions:}

If the decrees indicated the existence of famines, the temples' inscriptions, on the contrary, strongly deny that. According to Vandier, sentences such as: there was no year of famine in my time, constantly appear on the walls of the temples of Kom-Ombo, Philæ, Dendera and especially Edfu: the expressions vary, but the meaning is the same (Vandier, 1936). It is possible that these sentences are a simple formula and the fact that these expressions are found in all reigns and even in Roman times supports this supposition. However, Vandier believed that at least in the beginning it should be seen more as a lie/denial of the system rather than a formula. To accept Vandier opinion, we can concentrate, for instance, on the inscriptions of Edfu which are particularly significant in this regard. Most of the texts of this temple, denying the famine, in fact dated back to the reign of Ptolemy IV. Sources (the Greek historian Polybius) proved that shortly after the battle of Raphia 217 BC, Egypt was devastated by a revolt that almost degenerated into civil war. Emboldened by the armed service that Ptolemy IV had to impose on them to achieve victory (Polybius, Historiae 5.107.1 \& 14.107.1). The revolt must have been long and terrible (Clarysse, 2004). In this case no credit should be given to those texts denying any possible famine or food crisis during the civil war, moreover, it would be difficult to understand, that a king denied with insistence such a danger at a time even if there had not been a famine (food crisis), at least, there was a threat of it. The previously mentioned royal decrees specially the Rosetta decree under Ptolemy V confirms this hypothesis.

\section{Private Records:}

Ludlow \& Manning referred to a papyrus of a significance importance in providing us with the framework of the early Ptolemaic system, P.Tebt. III 703. It is crucial in presenting a notion of political and economic difficulties in Egypt between 245 and $240 \mathrm{BCE}$, as well as the administrative reactions to emergencies (Ludlow \& Manning, 2016). 
The P.Tebt. III 703, generally regarded as a memorandum from a dioiketes the head of the government financial administration to an oikonomos in a nome, offers valuable insights into the followed system, as well as its reliance on appropriate behavior of officials, particularly the oikonomos' duties, which comprise paying close attention to irrigation channels, agricultural and animal conditions and transportation, primarily of grain to Alexandria - all of which are constantly important to the kings, especially during times of crisis (Crawford, 1971, Cuvigny, 1985). Concerning the protection of Alexandria's food supply, the dioiketes advocated in such memorandum (P.Tebt. III 703, 3.70-87) as follows (Bagnall \& Derow, 2004):

"Take care that the grain in the nomes, ...... Take care also that the prescribed supplies of grain, of which I send you a list, are brought down to Alexandria punctually, not only correct in amount but also tested and fit for use".

The P.Tebt. III 703, which reflects the local reactions to emergencies, can be dated to the 240s B.C, is significant in that it depicts Egypt's political and economic difficulties between 245 and 240 B.C, as well as the government's efforts to manage and control food distribution with much particular care to Alexandria's grain supply.

Another response to low Nile flood crisis is documented in a Greek petition. Specifically, it is not dated however, some scholars dated it back to the middle of the third century B.C (Turner, 1984, Lukaszewicz, 1999), probably fitting the crisis and circumstances of $c a .245$ to 238 B.C (Manning, 2018).

The text, requesting a royal audience, was written most probably by a soldier known as Philotas living in Apollinopolis the Great, Edfu. The petition mentions a three years of Nile failure, and claims knowledge of a certain new irrigation "machine" that the use of which could "save" the country from famine and asks the king for 30 days sustenance and promises that within 50 days there would be instantly a plentiful harvest. In fact, it is still unknown what machine Philotas has invented, but some believe that it may be the saqiya (Ludlow \& Manning, 2016). The advent of the saqiya is generally dated to approximately this time, circa 240 B.C (Ludlow \& Manning, 2016,). According to Michael Lewis, various new water lifting machinery, known as rotating machines, were invented in Alexandria between 260 and 230 B.C (Lewis, 1997). Perhaps this coincided with the presence of Archimedes in Alexandria and his invention of the "Archimedean Screw" during the period from c. 287-212 B.C (Morelon, 1996). However, it's not clear whether the saqiya was developed in Alexandria in response to a particular crisis at the time, or if Philotas the petitioner improved on it. It is likely that Ptolemy III's strategy works well, the country, as well as agricultural production, eventually recovered from the 240s' potential problems. After a terrible earthquake in Rhodes in 227/226 BCE, Ptolemy III was capable of sending a substantial gift of grain to the island, amounting to 30 million liters of grain (Hollander \& Howe, 2020), as Polyb stated, it was one of the greatest supplies known from the ancient world (Polyb. 5.88.1-90.4).

Briefly, the previously mentioned evidences which reflects the Ptolemies response to unlikely circumstances of food shortages, implied that the scope of royal or other remedies were varied and, in some cases, as in Ptolemy III and Ptolemy V were innovative. Reasons of these shortages varied; natural resources which may change dramatically at any time, revolts, political unrests, wars, etc. but the possibilities of the administration system of the Ptolemies to react were each time quite different.

\section{Analysis and Discussions:}

The Kingship and the Nile are closely linked together. Kings were associated with the control of the flood waters (Aldred 1963). On the walls of the tomb chamber of the Pyramid of Unas 
(Pyramid. 388; and in Pyramid. 507-8), the king is poetically identified with the Nile flood. King Amenemhet I of Dynasty XII includes the occurrence of good floods among the reasons why he deserves the loyalty and gratitude of all his people (Wilson, 1956). Author as Ammianus Marcellinus knew that the Egyptians ascribed high flood or famines to the quality of their king, not, to his quality as an administrator, but to his effectiveness as an organ of integration. (Erman,1927). Since maintaining ma'at, by some supernatural power, was the primary duty of the king, the occurrence of disorder, of famine, and failure of the floods, would mean that the god-king had somehow failed in his prime duty (Bell, 1971).

In the Pharaonic period, evidence of action taken concerning managing food crisis on the part of the central government is scanty and management were left most of the time to the local officials especially during the $1^{\text {st }}$ Intermediate Period, where water management and the distribution of food was being controlled locally. To overcome damages caused by floods, great efforts were made through the construction of canals. (Strauss-Seeber, 2007). One obvious exception of country level management was in the Old Kingdom Sadd el Kafara dam, the construction of which might have been regarded as an experiment not worth repeating, after its collapse it seems, no attempt was made to repair it. It was the only dam constructed in Egypt in the Old Kingdom. It is noteworthy that none of the inscriptions describing food crisis mention the name of any king, except maybe in the Late period. The consequences of low or destructive inundations depended largely on the ability of administrative officials' state or local to overcome and handle food crises: by sufficient storage of food from one year to the next and using an efficient redistribution system (Meeks, 2003). Conversely, famine clearly correlates with mismanagement of the state administration. Most Egyptologists attempt to explain the collapse of the Old Kingdom due to the declining power and wealth of the king and the growing power and independence of the provincial nobility.

During the Ptolemaic Period, the country witnessed several food crises which were consequence of not only climatic change and bad Nile Flood, but also of the collapse of the system of production, consumption and distribution of critical foodstuffs. An analysis of the impact of food crisis or famines and the way they were managed are involved through the investigation of the official material and documents of the Ptolemies in order to understand their concerns and management responses to actual or anticipated food crises.

The investigations revealed that food shortage/crisis that faced the Ptolemies, did not reach to such dramatic famine that accompanied the decline of the Old Kingdom, and were frequent and occurred unpredictably. The annual Nile flood had a significant influence on Egyptian agriculture, its levels could predict the grain and harvest (Diodorus, I.36.12); thus, taxes were imposed based on flood levels. Consequently, the Ptolemaic kings installed Nilometers in temples along the Nile to fairly assess taxes (Angelakis \& Mays, 2014). The level of 16 cubits was considered the optimal level for the inundation of fields from the Graeco-Roman period (Said, 2013). Pliny (Plin. Nat. 5.10) wrote that when the flood level was 12 cubits, it meant starving, and even 13 cubits meant hunger, but 14 cubits represented joy, 15 cubits meant liberty, and 16 cubits meant absolute delights. Pliny also told us that, the largest documented increase is 18 cubits, which occurred during the reign of Emperor Claudius; the smallest is 5 cubits, which occurred in the year of the battle of Pharsalia (Plin. Nat. 5.10), during the reign of Cleopatra VII. It can be assumed that the Nilometer was used as measurement tool, for predicting potential crisis, within an elaborated protective strategy designed to buffer citizens against food shortage. Sometimes, local governor who were responsible for controlling food production and distribution, played a crucial role in the settling or reduction of food crises.

Examining the response to food crises and famines during Pharaonic and Ptolemaic Periods reveals continuity in management policies as well as interactions with Greek thoughts. The 
tables below (Tables. 1 - 2) show comparative between the collected data and evidences from the two periods.

Table 1. A Comparative Study of Food Crises in Pharaonic and Ptolemaic Periods

\begin{tabular}{|c|c|c|}
\hline Criteria & Pharaonic Period & Ptolemaic Period \\
\hline Reasons of Food Crisis & $\begin{array}{l}\text { Climate change, flood failure, } \\
\text { civil wars. }\end{array}$ & $\begin{array}{l}\text { Climate change, series of failed floods, } \\
\text { socioeconomic stress, funding wars, } \\
\text { exporting grains. }\end{array}$ \\
\hline Dating of Food Crisis & $\begin{array}{l}\text { Examples show all periods } \\
\text { from the Old Kingdom till the } \\
\text { Late Period, the most } \\
\text { documented was that of the } 1^{\text {st }} \\
\text { Intermediate Period through } \\
\text { autobiographical records. }\end{array}$ & $\begin{array}{l}\text { The evidences did not reveal the whole } \\
\text { truth, it even denied it in some cases. } \\
\text { However, the available documents } \\
\text { indicated that examples began since the } \\
\text { beginning of the era of Alexander the Great } \\
\text { and continued to occur frequently until the } \\
\text { end of the Ptolemaic period. Perhaps it was } \\
\text { also one of the reasons for the collapse of } \\
\text { the Ptolemaic Dynasty. }\end{array}$ \\
\hline $\begin{array}{l}\text { People Responsible for } \\
\text { Management of Food Crisis }\end{array}$ & $\begin{array}{l}\text { Officials mainly and kings } \\
\text { occasionally }\end{array}$ & $\begin{array}{l}\text { The kings mainly and individuals } \\
\text { occasionally }\end{array}$ \\
\hline $\begin{array}{l}\text { Methods of Food Crisis } \\
\text { Management }\end{array}$ & $\begin{array}{l}\text { Digging of canals, building of } \\
\text { dams, taxes, opening of grain } \\
\text { houses and distributing of } \\
\text { food }\end{array}$ & $\begin{array}{l}\text { Forbidding exports, importing grain, } \\
\text { inventing new hydraulic water machines, } \\
\text { debt cancellation, amnesty, reduce taxes, } \\
\text { offering and praying to God, controlling the } \\
\text { distribution of supplies throughout Egypt, } \\
\text { opening the royal granary storages to the } \\
\text { starving public. }\end{array}$ \\
\hline
\end{tabular}

According to data tabulated in Table1, reasons of threats of famine or food crises during the two periods are almost similar and most of them are natural caused and related to the climate change or the bad flooding of the Nile River. However, new reasons appeared during the Ptolemaic Period, mainly human caused, as a result of wars and external expansions or as a result of the unfair distribution of grain or heavy exports.

Ancient evidences and documents proved that Egypt suffered from the dangers of food crisis throughout the two studied periods, sometimes it reached the highest levels of threats, as occurred during the First Intermediate Period.

Although recent studies have proven that Egypt was exposed to severe periods of climate change during the Ptolemaic Period, as well as periods of unrest and instability, Ptolemaic official documents, particularly the temples' inscriptions, strongly deny the country's exposure to this kind of threat, perhaps that was part of the Ptolemies plan to control the situation.

The comparison also showed that officials during the Pharaonic Period had a greater role than Kings in dealing with the food crisis situations, on the other hands the Ptolemies had the upper hand. Generally, potential solutions followed by either rulers or officials are closely linked to their perspectives, beliefs, objectives, needs, ambitions, and behaviors.

The policy of the ancient Egyptian kings tended to pay attention to the Nile River and major irrigation projects, such as purifying and digging canals, building dams, expanding the crops and storing the surplus in royal warehouses. The Ptolemies followed the same policy of the Egyptians, but with the emerge of some new methods, that appear to be influenced by the Greek economic thought, such as forbidding exports, importing food, inventing new machines and debt cancellation to deal with unlikely circumstances that threatens the order.

Table 2: Displaying Most Common Terms used to describe Food Crisis in Pharaonic and Ptolemaic Periods 


\begin{tabular}{|c|c|}
\hline Terms used to explain Food Crises & Dating of the Terms used \\
\hline $\begin{array}{l}\text { snb-rnbt } \\
\text { smb-ib } \Gamma_{\perp} \text { in } \\
\text { snb-ib } \\
\text { (Wb IV, p.160) }\end{array}$ & Old Kingdom/ Ptolemaic \\
\hline $\begin{array}{l}0 \times 1 \\
s^{\top} n h-s w 3 \\
\text { (Wb III, p.435) }\end{array}$ & Old Kingdom \\
\hline 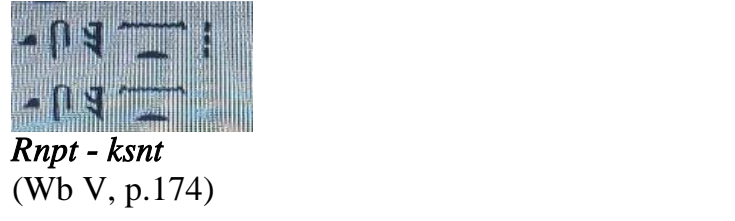 & $\begin{array}{l}1^{\text {st }} \text { Intermediate Period }\left(10^{\text {th }}\right. \\
\text { dynasty })\end{array}$ \\
\hline $\begin{array}{l}\frac{1}{(-1} \\
\text { (Wb IV, p.402) }\end{array}$ & $1^{\text {st }}$ Intermediate Period \\
\hline $\begin{array}{l}\text { Wgg } \\
\text { (Wb I, p.377.18) }\end{array}$ & $11^{\text {th }}$ dynasty \\
\hline 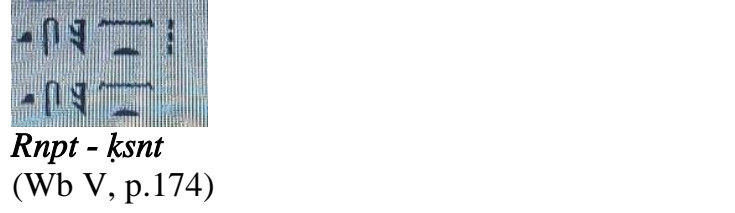 & $11^{\text {th }}$ Dynasty/ Ptolemaic \\
\hline 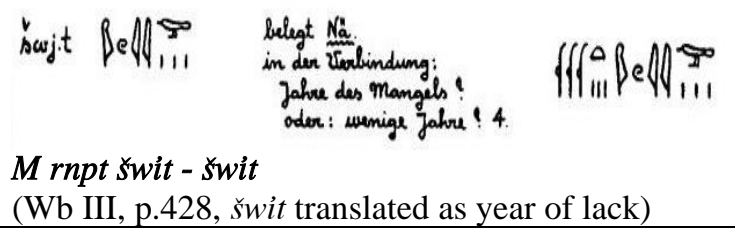 & New Kingdom \\
\hline
\end{tabular}




\begin{tabular}{|c|c|}
\hline 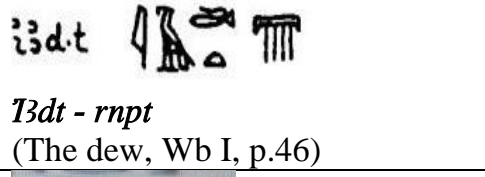 & New Kingdom/ Ptolemaic \\
\hline $\begin{array}{l}R+T= \\
\bar{I}= \\
\text { s3 rnpt - snni } \\
\text { (Wb III, p.416) }\end{array}$ & Ptolemaic \\
\hline $\begin{array}{l}1 \geq 1 \\
1 \mathbf{X} *(7 \\
1915\end{array}$ & Ptolemaic \\
\hline $\begin{array}{l}\text { Kn-rnpt } \\
\text { (Wb V, p.48) }\end{array}$ & Ptolemaic \\
\hline 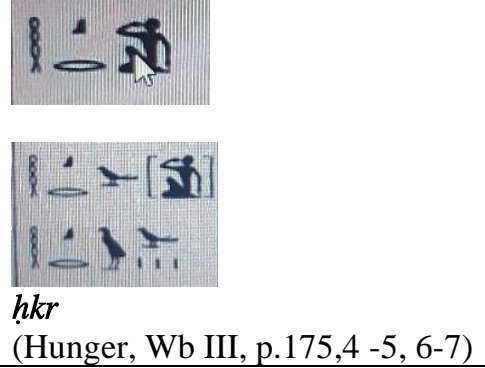 & $\begin{array}{l}\text { During Pharaonic and } \\
\text { Ptolemaic period }\end{array}$ \\
\hline
\end{tabular}

\section{Commentary}

The word $h k r$ and $w g g$ are the most common words used to describe famine and hunger in ancient Egypt. $h k r$ was mentioned in the pyramids of Unas, Teti, Pepi II and several papyri. The word $t s w$, which appears in several of the famine texts of the Pharaonic period, did not appear in the Ptolemaic period and is generally translated sand- banks by Egyptologists. Vandier translates $\underline{t} s w$ as year(s) of low Nile, and thus of famine, but consider it highly probable that $t s w$ meant poor Nile by metonymy, and famine by consequence. The word $t s w$ has not been found in famine texts outside the First Intermediate Period. (Vandier 1936). There are common words describing food crisis in the Pharaonic and Ptolemaic periods like $h k r, i 3 d t$, rnpt-ksnt and $s n b-i b$, while some words were only common in the Pharaonic period like $\left.w g g, s^{\top} n h \underline{h} s w\right\}, t s w$, $m$ rnpt šwit, and others common during the Ptolemaic period as s3-rnpt, snni, snb-rnpt, d3it$r n p t, k n$-rnpt. Some of the interesting words describing famines are $s n b$-ib, literally the heart is healthy and snb-rnpt. Their meaning has been estimated by the existence of a root snb meaning "sterility". 


\section{Conclusions}

The study shed light on food crises/food shortage as a result of both natural and economic issues. According to the ancient Egyptians, the king was responsible for maintaining ma'at, by a supernatural power, the occurrence of disorder, low Nile floods and famines would be explained as the god-king failing in his major duty. Thus, Food crises in ancient Egypt are sometimes associated with corrupted rulers, inefficient or preoccupied with interior or foreign enemies. Food crisis as a result of low floods was estimated by some researchers as the cause of the collapse of centralized administration such as the Old Kingdom. There was more than a reason for food crises in ancient Egypt and the Ptolemaic periods, which were consequences of not only climatic change and bad Nile Flood, but also of the collapse of the system of production, consumption and distribution of critical foodstuffs. Food crises were managed through digging canals, building dams, installations of Nilometers, payment of taxes, controlling the distribution of food, inventing new machines, also through prayers to gods. In the Ptolemaic period, most of the documents indicate food shortages rather than great famines. Where royal decrees indicated the existence of famines, the temples' inscriptions, strongly deny that. Probably it was a lie/denial of the system to express stability and control over the country rather than a repeated formula. The main difference of food crisis management in the Ptolemaic Period was the Ptolemies new broader frameworks of management that consisted of some different skills and strategies in dealing with food crises such as; preventing exports and monopolizing the market, importing grain into Egypt from Syria, Phoenicia, Cyprus and from other places, which did not occur in Pharaonic Egypt. In additions, the study revealed some common terms used in both periods to describe food crisis like $h k r$, $i 3 d t$, rnpt-ksnt, and snb-ib. 


\section{References}

Aldred, Cyril (1963), The Egyptians, Praeger, New York. 1965 Egypt to the End of the Old Kingdom, Mc- Graw-Hill, New York.

Alien,Lindsay\& Prentise,Andrew, (2013),Encyclopedia of Human Nutrition

Andelman, D. A., \& Pauker, B. (2010). Water Wars? A Talk with Ismail Serageldin. World Policy Journal.

Angelakis, A., \& Mays, L. (2014). Evolution of water supply through the millennia. IWA Publishing.

Appian, Civil Wars, IV, 61

Arregui, A., Mackenthun, G., \& Wodianka, S. (2020). DEcolonial Heritage: Natures, Cultures, and the Asymmetries of Memory. Waxmann.

Ashton, S. A. (2009). Cleopatra and Egypt. John Wiley \& Sons.

Athenaeus of Naucratis. "Deipnosophistae". Book 5, Chapter 40.

Badian, E., \& Sherk, R. K. (1985). The Hellenistic Age from the battle of Ipsos to the death of Kleopatra VII (No. 3). Cambridge University Press.

Bagnall, R. S., \& Derow, P. (2004). Historical sources in translation: the Hellenistic Period.

Barguet, P., (1953), La Stèle de famine (Vol 24), Cairo.

Bell, B., (1971), The Dark Ages in Ancient History I. The First Dark Age in Egypt.

Bevan, E. R. (1968). The House of Ptolemy: a history of Egypt under the Ptolemaic dynasty.

Birch, S. (1874). Records of the Past: Being English Translations of the Assyrian and Egyptian Monuments (Vol. 8). S. Bagster and sons.

Borchardt, Ludwig, (1924), Catalogue des Statues et Statuette du Musee du Caire

Bosworth, A. B. (2016). Cleomenes (3), of Naucratis, financial administrator. In Oxford Research Encyclopedia of Classics.

Bourriau, Janine, \& Porter,Roy Sydney,(1992), Understanding Catastrophe. Cambridge.

Bowman, A. K., Champlin, E., \& Lintott, A. (Eds.). (1996). The Cambridge Ancient History (Vol. 10). Cambridge university press.

Breasted, James Henry (1906), Ancient records of Egypt I, The First to the Seventeenth Dynasties

Budge, E. W. (2014). The Decrees of Memphis and Canopus: Vol. III (Routledge Revivals): The Decree of Canopus. Routledge.

Bundy, J., Pfarrer, M. D., Short, C. E., \& Coombs, W. T. (2017). Crises and crisis management: Integration, interpretation, and research development. Journal of management, 43(6), 1661-1692.

Buraselis, K. (2013). Ptolemaic grain, seaways and power. The Ptolemies, the Sea and the Nile. Studies in Waterborne Power, 97-107.

Casson, L. (1971). Ships and Seamanship in the Ancient World (Princeton/New Jersey). 
CICARMA, A. E. (2018). Zenith of the Ptolemies. The Reigns of Ptolemy III Euergetes and Ptolemy IV Philopator. Their Royal Titulary and Epithets, Ascension to the Throne, Military Campaigns, Administration, Patronage of the Arts and Culture and Legacy. Scientific Journal of Humanistic Studies, 10(18).

Clarysse, W. (2004). The great revolt of the Egyptians (205-186 BC). The Center for the Tebtunis Papyri Lecture Series of University of California, 16.

Cole, S. E. (2018). Beyond the Nile: Egypt and the classical world. Getty Publications.

Collins, A. W. (2012). Cleomenes of Naucratis, Heroonpolis, and the revenue from Red Sea trade under Alexander the Great. Zeitschrift für Papyrologie und Epigraphik, 237-242.

Connor, A. J. (2015). Temples as Economic Agents in Early Roman Egypt: The Case of Tebtunis and Soknopaiou Nesos. University of Cincinnati.

Driaux Delphine, (2020), Toward a Study of the Poor and Poverty in Ancient Egypt: Preliminary Thoughts

Drioton, Etienne (1942), Une representation de la famine sur un bas- relief 6gyptien, BIE 25:4553

Droysen, J. G. (1877), Geschichte des Hellenismus, 2 voll. Hamburg: F. Perthes.

El Bedawy,R.,(2014),Water Resources Management: Alarming Crisis for Egypt

Erman, Adolf (1927), The Ancient Egyptians: a sourcebook of their writings, Harper Torchbooks

Fahlbusch, H. (2009). Early dams. Proceedings of the ICE - Engineering History and Heritage. 162(1), 01, $13-18$

Fekri, Hassan, (2007), "Droughts, Famine and the Collapse of the Old Kingdom: Re-Reading lpuwer"in The Archaeology and Art Of Ancient Egypt,Essays in Honor of David B. O'Connor, Annales Du Service Des Antiquities' De L'Egypte. Cahier N 36 Volume I CASAE 362007 pp,257-277

Forsyth, P. Y. (1988). In the wake of Etna, 44 BC. Classical Antiquity, 7(1), 49-57.

Frankfort, Henrim, (1948), Kingship and the Gods, University of Chicago Press.

Gardiner, Sir Alan (196I) ,Egypt of the Pharaohs, Clarendon Press, Oxford.

Garnsey, P. (1988). Famine and food supply in the Graeco-Roman world: responses to risk and crisis. Cambridge University Press.

Goettling, K. W. (Ed.). (1830). Aristotelous Oikonomikos. Anōnymou Oikonomika. Philodēmou Peri kakiōn kai tōn antikeimenōn aretōn [theta, ie 9].: Coniuncta edidit et adnotationem adiecit Carolus Goettlingius. Sumptibus CH Walzii.

Grainger, J. D. (2010). The Syrian Wars. Brill.

Grapow, Hermann, (1932),Urkunden Des Agyptischen Altertums,I, Leipzig.

Haiying, Y. (1998). The Famine Stela: A Source-Critical Approach and Historical-Comparative Perspective. In Proceedings of the Seventh International Congress of Egyptologists. Leuven: Peeters (Vol. 515, p. 21).

Hauben, H. (1981). A Neglected Detail of Philopator's Policy. L'Antiquité Classique, 398-403. 
Hayes, William C. (I96I) ,The Middle Kingdom of Egypt, CAH I, ch. 20 (fasc. 3)

Hölbl, G. (2013). A history of the Ptolemaic empire. Routledge.

Hollander, D., \& Howe, T. (2020). A Companion to Ancient Agriculture (Blackwell Companions to the Ancient World) (1st ed.). Wiley-Blackwell.

Hossein-Zadeh, I. (2014). Beyond Mainstream Explanations of the Financial Crisis: Parasitic Finance Capital. Routledge.

Hudson, M. (1993). The lost tradition of biblical debt cancellations (pp. 1-32). New York: Henry George School of Social Science.

John, B.,( 2011), The Story of the Nile. BBC History

Justinus, M. J. (2011). Justin: Epitome of the Philippic History of Pompeius Trogus: Volume II: Books 13-15: The Successors to Alexander the Great (Vol. 2). Oxford University Press.

Kemp, Barry,(1991), Ancient Egypt: Anatomy of a Civilization

Larry, W. M. (2010). Ancient Water Technologies. New York, Springer

Lehmler, C. (2005). Syrakus unter Agathokles und Hieron II.: die Verbindung von Kultur und Macht in einer hellenistischen Metropole. Verlag Antike.

Lewis, M. J. T. (1997). Millstone and Hammer: the origins of water power. University of Hull Press.

Lewis, S.L., Maslin, M.A., (2015). Defining the Anthropocene. Nature 519, pp.171-180.

Leyden, Papyrus Magique ,I

Lloyd, A. B. (2014). Ancient Egypt: state and society. Oxford University Press.

Ludlow, F., \& Manning, J. G. (2016). 10 Revolts under the Ptolemies: A Paleoclimatological Perspective. In Revolt and Resistance in the Ancient Classical World and the Near East (pp. 154-171). Brill.

Mahaffy, J. P. (2014). The Empire of the Ptolemies. Cambridge University Press.

Manning, J. G. (2018). The open sea: the economic life of the ancient Mediterranean world from the Iron Age to the rise of Rome. Princeton University Press.

Manning, J. G., Ludlow, F., Stine, A. R., Boos, W. R., Sigl, M., \& Marlon, J. R. (2017). Volcanic suppression of Nile summer flooding triggers revolt and constrains interstate conflict in ancient Egypt. Nature communications, 8(1), 1-9.

Mcconnell, J. R., Sigl, M., Plunkett, G., Burke, A., Kim, W. M., Raible, C. C., ... \& Steffensen, J. P. (2020). Extreme climate after massive eruption of Alaska's Okmok volcano in 43 $\mathrm{BCE}$ and effects on the late Roman Republic and Ptolemaic Kingdom. Proceedings of the National Academy of Sciences, 117(27), 15443-15449.

Mokyr, J. (Ed.). (2003). The Oxford encyclopedia of economic history (Vol. 5). Oxford University Press on Demand.

Monson, A. (2012). From the Ptolemies to the Romans: political and economic change in Egypt. Cambridge University Press. 
Morelon, R. (1996). Encyclopedia of the History of Arabic Science: Technology, alchemy and life sciences (Vol. 3). CRC Press.

Muhs, B. (2016). The ancient Egyptian economy: 3000-30 BCE. Cambridge University Press.

Newberry,Percy, (1893), Beni Hasan,I , London.

Nicoli ,Kathleen., (2020),'Is the Past key to the Present? Observations of cultural continuity and resilience reconstructed from geoarchaeological records", in Quaternary International , Volume 545, pp.119-127.

O'Neil, J. L. (2012). The Native revolt against the ptolemies (206-185 BC): achievements and limitations. Chronique d'Egypte, 87(173), 133-149.

Peet,( 1930), Theban Great Tomb Robberies of the Twentieth Dynasty, Oxford.

Petrie, Flinders, (1909), Qurneh, London.

Pinch, G. (2004). Egyptian mythology: A guide to the gods, goddesses, and traditions of ancient Egypt. Oxford University Press, USA.

Roller, D. W. (2010). Cleopatra: a biography. Oxford University Press.

Rostovtzeff, M. I. (1953). The social \& economic history of the Hellenistic world (Vol. 3). Clarendon Press.

Rutz, Ana, ( 2001), The Spirit of Ancient Egypt

Said, R. (2013). The River Nile: geology, hydrology and utilization. Elsevier.

Sally Katary, Land Tenure (to the end of the Ptolemaic Period), (2012), UCLA Encyclopedia of Egyptology, Laurentian University, Sudbury, Ontario, Canada, escholarship.org ).

Schnitter,N. J. (1994), A history of dams, the useful pyramids. Rotterdam,Netherlands

Sciencedaily.com, August 27, 2012

ScienceDaily: Your source for the latest research news. (2012). ScienceDaily. Retrieved August 16, 2021, from https://www.sciencedaily.com/

Seeger, M. W., Sellnow, T. L., \& Ulmer, R. R. (1998). Communication, organization, and crisis. Annals of the International Communication Association, 21(1), 231-276.

Seneca, question about nature, 4A.2.16

Shabrawy, G., Dumont, H. (2009), The Fayum Depression and Its Lakes. The Nile: Origin, Environments, Limnology and Human Use.

Sharma,V.M.\&Saxena K.R.,(2004),Dams: Incidents and Accidents, Balkema Publishers.

Smith, William Stevenson (1965), The Art and Architecture of Ancient Egypt, Penguin Books, Baltimore.

Strauss-Seeber, Christine (2007), Der Nil : Lebensader des Alten Agypten

Tylor, The Tomh of Sebeknakht,

UCLA Encyclopedia of Egyptology, escholarship.org; Internet Ancient History Sourcebook: Egypt sourcebooks.fordham.edu ) 
Vandier, J. (1936). La famine dans l'Égypte ancienne. Recherches d'archeologie, de philologie et d'histoire.

Vandier, Jacques (1936) La famine dans l'Egypte Ancienne, Le Caire.

Vandier, Jacques, (1950), Mo'alla, , Le Caire.

Vandorpe, K. (2005). Agriculture, temples and tax law in Ptolemaic Egypt. Na.

Vandorpe, K. (Ed.). (2019). A Companion to Greco-Roman and Late Antique Egypt. John Wiley \& Sons.

Venette, S. J. (2003). Risk communication in a high-reliability organization: APHIS PPQ's inclusion of risk in decision making. North Dakota State University.

Verordnung über die Versorgung Alexandreias :: Ägyptisches Museum und Papyrussammlung: Museum-digital:staatliche museen zu berlin. (2021b, July 23). Ägyptisches Museum und Papyrussammlung. Https://smb.museum-digital.de/index.php?T=objekt\&oges=6117

Vikentiev, Vladimir,(1930), La Haute Crue du Nil et l'averse de l'an 6 du Roi Taharqa. Le Caire.

Whittaker, C. R. (2020, August). Trade and famine in classical antiquity. Cambridge Philological Society.

Wilson, John A. (1955), translations from Ancient Near Eastern Texts (ANET), ed. J. B. Pritchard, Princeton University Press.

Wilson, John A. (1956 )The Culture of Ancient Egypt, University of Chicago Press.

Yofee, N., (2019), The Evolution of Fragility: Setting the Terms 